\title{
Stability of marine phytoplankton communities facing stress related to global change: Interactive effects of heat waves and turbidity
}

\author{
Merle Remy ${ }^{\mathrm{a}}$, Helmut Hillebrand ${ }^{\mathrm{a}, \mathrm{b}}$, Sabine Flöder ${ }^{\mathrm{a}, *}$ \\ a Plankton Ecology, Institute for Chemistry and Biology of the Marine Environment (ICBM), Carl-von-Ossietzky University Oldenburg, Schleusenstrasse 1, 26382 \\ Wilhelmshaven, Germany \\ ${ }^{\mathrm{b}}$ Helmholtz-Institute for Functional Marine Biodiversity at the University of Oldenburg (HIFMB), Ammerländer Heerstrasse 231, 26129 Oldenburg, Germany
}

\section{A R T I C L E I N F O}

\section{Keywords:}

Stability

Multiple stressors

Phytoplankton

Global change

Heat waves

Turbidity

Biodiversity

Productivity

\begin{abstract}
A B S T R A C T
According to climate models, coastal ecosystems will face an increased frequency of heat waves and increased turbidity due to terrestrial sediment run-off induced by increasing precipitation. Several studies have examined the effects of heat waves and turbidity separately, whereas this study analysed the individual effects of both stressors as well as their interaction, because stressors affect communities differently when acting in combination. Using a factorial experimental design, we simulated heat waves $\left(22^{\circ} \mathrm{C}\right.$ and $26^{\circ} \mathrm{C}$ compared to an $18{ }^{\circ} \mathrm{C}$ control) and turbidity (sediment addition). The response of the phytoplankton community was analysed for the aggregate parameters biovolume and diversity index $\left(\mathrm{H}^{\prime}\right)$, as well as for community composition. Heat waves had a significant negative effect on biovolume, whereas turbidity tended to affect biovolume positively. Repeated measures ANOVA revealed significant interactions of heat waves and turbidity for $\mathrm{H}^{\prime}$ and community composition. Strong heat waves $\left(26^{\circ} \mathrm{C}\right)$ alleviated the otherwise positive effect of turbidity on $\mathrm{H}^{\prime}$, i.e. highest diversity remained in the turbid control. Diatoms gained dominance in the control and the $22{ }^{\circ} \mathrm{C}$ heat wave treatment with Cylindrotheca closterium being the successful competitor. At $26^{\circ} \mathrm{C}$ this species was lost and small flagellates dominated the experimental communities. Future increases in heat wave intensity and frequency may thus induce major changes in phytoplankton community structure whereas algae might profit from increased turbidity as an additional source of nutrients.
\end{abstract}

\section{Introduction}

Global environmental change, in particular warming, influences ecosystem composition in aquatic and terrestrial systems (Burgmer et al., 2007; Seifert et al., 2015; Stocker, 2014; Stocker et al., 2014). Elevated sea surface temperature causes rapid changes in aquatic communities including changes in the abundance and spatial or seasonal distribution of marine phytoplankton as well as temporal mismatches between trophic levels (Field et al., 2014; Poloczanska et al., 2013; Thiede et al., 2016). There is an ongoing debate whether altered stratification and species composition will lead to a global decline in phytoplankton productivity (Boyce et al., 2010; Lewandowska et al., 2012; McQuatters-Gollop et al., 2011), which would be a severe change of the Earth system as marine phytoplankton provides nearly half of the global primary production (Behrenfeld et al., 2006; Thomas et al., 2012; Valiela, 2013). Additionally, phytoplankton in the ocean plays a major role in the global carbon, nitrogen and phosphorous cycles (Thomas et al., 2012) and as a base of marine food webs. A change in phytoplankton biodiversity and abundance will thus ultimately have consequences for higher organisms as well as for the economy with regard to fisheries (Hays et al., 2005).

Depending on the emission scenario of the intergovernmental panel on climate change (IPCC), future temperature will rise between $2{ }^{\circ} \mathrm{C}$ and $5{ }^{\circ} \mathrm{C}$ by the end of the 21st century (Field et al., 2014). The ocean stores $90 \%$ of the planet's heat content and since the 1970s, water temperature, particularly close to the surface, has warmed already $0.11^{\circ} \mathrm{C}$ per decade (Boyd et al., 2010; Field et al., 2014). This process is likely to continue and especially latitudes $>40^{\circ}$ are warming increasingly (Poloczanska et al., 2013). On a regional scale, sea surface temperatures in the North Sea have risen more than in any other area of the North-East Atlantic over the past 25 years, with temperature increases of $1{ }^{\circ} \mathrm{C}$ to $2{ }^{\circ} \mathrm{C}$ and a further predicted increase of $2.5^{\circ} \mathrm{C}$ (Steege and Köthe, 2015; Thiede et al., 2016).

Most studies evaluate the consequences of such changes in mean annual temperature, but also the frequency and intensity of heat waves is likely to increase (Field et al., 2014; Hov et al., 2013). Heat waves, in this context, are defined as a period of at least three to five days during which mean or maximum temperature anomalies were at least $3-5{ }^{\circ} \mathrm{C}$

\footnotetext{
* Corresponding author.

E-mail address: sabine.floeder@uni-oldenburg.de (S. Flöder).
} 
above normal (Hobday et al., 2016; Meehl and Tebaldi, 2004). Such heat waves affect marine ecosystems with respect to invertebrate, fish and macroalgal mortality, and the occurrence of algal blooms, as events in the North-western Mediterranean in 2003 (Garrabou et al., 2009) and heat waves in 2011 along the western Australian coast (Moore et al., 2012; Rose et al., 2012) have shown.

In addition to other effects of global change, like ocean acidification and sea level rise, increasing windiness and rainfall reduced light availability in the North Sea over the second half of the 20th century (Capuzzo et al., 2015). Further sources for additional sediment input into the ocean are coastal erosion and rivers. Although increasing coastal erosion is related to changes in wind and wave activity (Capuzzo et al., 2015), evidence for increased sediment fluxes from rivers to oceans varies strongly between world regions depending for instance on precipitation and the existence of dams and water reservoirs (Walling, 2009). Yet, the predicted increase in precipitation will likely affect sediment run-off and resuspension.

This study analyses the effects caused by heat waves and turbidity on phytoplankton communities. Particular focus lies on the interaction of the two stressors because in natural systems stressors usually act in combination (Flöder and Hillebrand, 2012; Folt et al., 1999; Segner et al., 2014). Individual physiological processes as well as ecological interactions are interdependent, which makes an interaction of stressors very likely (Breitburg and Riedel, 2005). However, it is more difficult to examine the effects of multiple stressors than of single stressors and it is unfeasible to asses all combinations of multiple stressors (Hooper et al., 2013). Therefore, stressors are often tested individually in laboratory experiments. The focus is thereby on the properties of the stressor instead of the traits of the biological receptor, for instance marine phytoplankton, which would ultimately show a species-specific reaction toward the stressor (Segner et al., 2014). This sometimes leads to surprising results when combined stressors are examined, because the effects can be less, larger or qualitatively different than what was predicted from individual stressors (Breitburg and Riedel, 2005; Segner et al., 2014).

Although the response of phytoplankton to temperature and turbidity as single stressors has been well studied (Behrenfeld et al., 2006; Boyce et al., 2010; de Jorge and van Beusekom, 1995; Dzialowski et al., 2008; Lewandowska et al., 2012; Seifert et al., 2015; Sloth et al., 1996), until recently, only few studies have analysed the effect of temperature in combination with turbidity (Zehrer et al., 2015). As temperature has direct metabolic effects on cellular processes and often interacts with other factors such as light and nutrients (Boyd et al., 2010), this study focuses on the effects of an interaction between heat wave and turbidity on biovolume, diversity (number of species and their relative abundance as defined by the diversity index $\mathrm{H}^{\prime}$ (see Washington, 1984) and taxonomic composition of an assembled phytoplankton community. We used a factorial approach to examine the effects of multiple stressors, temperature and turbidity, on the stability of a phytoplankton community and to answer the following research questions:

1) What effects do the stressors heat wave and turbidity have on the phytoplankton community, when they are applied separately?

2) When applied simultaneously, what kind of interaction will there be between heat wave and turbidity?

3) How severely is the stability of the phytoplankton community affected and to what degree does it recover?

\section{Materials and methods}

\subsection{Experimental conditions}

Four phytoplankton groups were used for the study: diatoms (Coscinodiscus granii, Leptocylindrus danicus, Thalassiosira sp., Pseudonitzschia sp., Cylindrotheca closterium, Chaetoceros sp.), chlorophyceae (Chlamydomonas sp.), dinoflagellates (Prorocentrum micans,
Scrippsiella trochoidae) and cryptophyceae (Rhodomonas salina). These microalgae belong to principle taxa of phytoplankton and are cosmopolitan and species that also occur in the North Sea (Boyd et al., 2010).

The algae were taken from the ICBM culture collection and grown on f/2-Medium (Guillard, 1975; Guillard and Ryther, 1962). During the experiment, phytoplankton communities ( $150 \mathrm{~mL}$ in Erlenmeyer flasks) were grown semi-continuously whereby $50 \mathrm{~mL}$ of medium was exchanged three times a week under sterile conditions. The experiment was conducted in a constant temperature room $\left(18^{\circ} \mathrm{C}\right)$. Light intensity was $40-45 \mu \mathrm{mol}$ photons $\mathrm{m}^{-2} \mathrm{~s}^{-1}$, with a day-night-cycle of $12 \mathrm{~h}$. The algae were kept in suspension using a shaker-table $(100 \mathrm{rpm})$. To compensate for the slightly uneven lighting, the experimental cultures were randomly arranged on the shaker-table and their position was changed, whenever culturing work was done.

\subsection{Experimental design}

As we aimed to examine the effects of two combined stressors, heat wave and turbidity, three different temperature levels $\left(18^{\circ} \mathrm{C}, 22^{\circ} \mathrm{C}\right.$, $26^{\circ} \mathrm{C}$ ) were established and half of the respective replicates were additionally treated with sediment to simulate turbidity. Temperature levels were chosen with regard to a possible temperature development during heat waves in temperate waters, like the North Sea, as well as with regard to marine heat waves that have already occurred (Garrabou et al., 2009). The control was kept at $18^{\circ} \mathrm{C}$, simulating warm summer temperature in the North Sea (Loewe et al., 2013). Heat waves lasted for 14 days and peaked at $26^{\circ} \mathrm{C}$ for the extreme heat wave $\left(+8{ }^{\circ} \mathrm{C}\right)$ and $22{ }^{\circ} \mathrm{C}\left(+4{ }^{\circ} \mathrm{C}\right)$ for the moderate heat wave, respectively. The increases in temperature were achieved with a heating pad (Biogreen "Heatingmat Sahara") underlying the Erlenmeyer flasks. A layer of fine grained sand ensured an equal heat distribution.

For the turbidity treatment, natural sediment was used. It was collected from the surface (upper $1-2 \mathrm{~cm}$ ) of the Jade Bight on 22.09.2015. After drying the sediment at $65^{\circ} \mathrm{C}$ and heat sterilization $\left(170{ }^{\circ} \mathrm{C}\right.$ for $2 \mathrm{~h}$ ), the sediment was homogenised using a ball mill and subsequently fractionated with a set of analytical sieves. Only the sediment fraction with a particle size $<160 \mu \mathrm{m}$ was used and $0.6 \mathrm{~g} \mathrm{~L}^{-1}$ was added to each replicate of the turbidity treatment.

The experimental set-up consisted of 24 Erlenmeyer flasks. Always eight flasks represented one temperature treatment of which four flasks were additionally treated with sediment $(2 \times 4 \times 3=24$ experimental units). The experiment was run for four weeks from 02.11.2015 to 30.11.2015.

Before starting the experiment, 20 cells of each phytoplankton species were measured with the computer program "CellP" (Olympus Soft Imaging Solutions $\mathrm{GmbH}$ ). Average individual biovolume was calculated according to Hillebrand et al. (1999) and Olenina et al. (2006). The experimental units were inoculated with all species contributing the same biovolume $\left(216.610^{-6} \mathrm{~mm}^{3} \mathrm{~mL}^{-1}\right)$. The nutrient concentrations of the f/2-medium $\left(432 \mu \mathrm{mol} \mathrm{N} \mathrm{L}^{-1}, 13.5 \mu \mathrm{mol} \mathrm{P} \mathrm{L}{ }^{-1}\right.$, $98 \mu \mathrm{mol} \mathrm{Si} \mathrm{L}{ }^{-1}$ ) were higher than those that naturally occur in the North Sea (for 2000-2007: 45-50 $\mu \mathrm{mol} \mathrm{N} \mathrm{L}^{-1}$, 0.9-1.1 $\mu \mathrm{mol} \mathrm{P} \mathrm{L}{ }^{-1}$, 25-30 $\mu \mathrm{mol} \mathrm{Si} \mathrm{L^{-1 }}$ (Loewe et al., 2013). Through nutrient saturation we wanted to make sure that a potential turbidity effect did not derive from additional nutrient supply. Although all nutrients were provided in great quantity, the effect was not derived.

The algae were grown for five days before the stressor regime began. On day five, sediment was added and the temperature treatment was started. The temperature was intended to remain stable for the following 14 days, whereas due to the semi-continuous design turbidity would decrease over time. From high turbidity after addition, the sediment would be washed out toward the end of the experiment (Fig. 1). Water temperature was monitored daily with an analogue thermometer and from day eleven on with a НОBO data logger in a separate Erlenmeyer flask for each higher temperature treatment. From day 5 , temperature was relatively stable for the $22{ }^{\circ} \mathrm{C}$ treatment $\left(21.9{ }^{\circ} \mathrm{C} \pm 0.4{ }^{\circ} \mathrm{C}\right.$ 


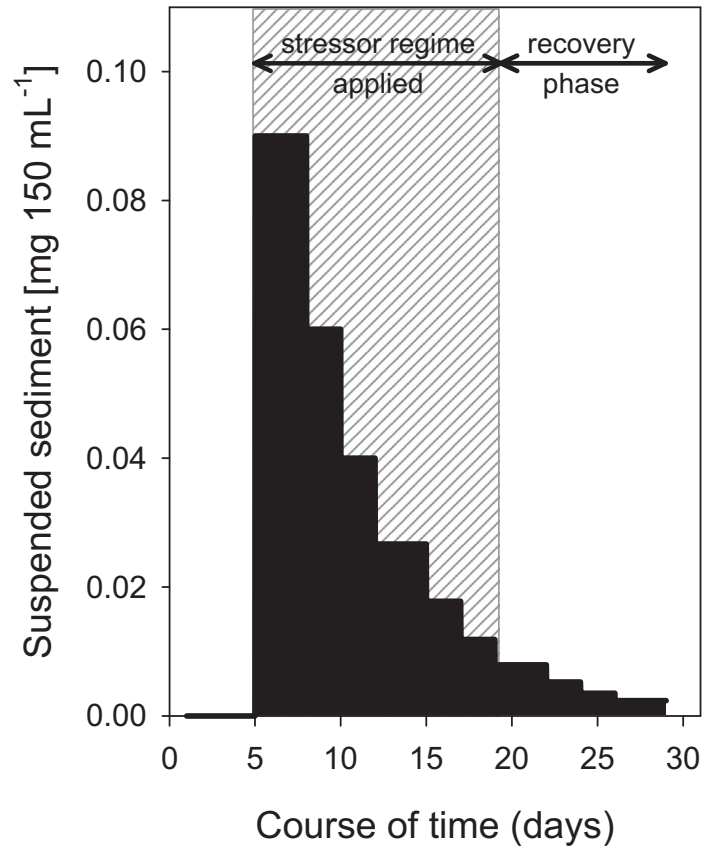

Fig. 1. Turbidity gradient over the course of the experiment (30 days). Calculated for $150 \mathrm{~mL}$. Grey area indicates time period of additional temperature application.

SD). In the $26^{\circ} \mathrm{C}$ treatment, temperature increased slowly toward an average of $24.7^{\circ} \mathrm{C} \pm 0.1{ }^{\circ} \mathrm{C}$ SD (maximum $26.7^{\circ} \mathrm{C}$ ), which was reached for the last six days of the experimental heat wave. On day 19, a ten-day recovery phase started with temperatures set back to $18{ }^{\circ} \mathrm{C}$ for the $22{ }^{\circ} \mathrm{C}$ and $26^{\circ} \mathrm{C}$ treatment. Due to the closed experimental design, no species could be introduced again after disappearing. However, species could "reappear" if they intermittently fell below the detection limit of the counting method.

\subsection{Sample analysis}

Samples $(50 \mathrm{~mL})$ were taken when medium was exchanged on day 5, 9, 15, 19, 24 and 29. After sampling, the Erlenmeyer flasks were randomly arranged within each temperature treatment. $20 \mathrm{~mL}$ of the solution were filtered and stored frozen $\left(-20^{\circ} \mathrm{C}\right)$ for later nutrient analysis (dissolved nitrogen, phosphorus and silicate) using an autoanalyser (Scalar Analytical, Breda, The Netherlands). The remaining $30 \mathrm{~mL}$ of algal solution were preserved with acidic Lugol's solution. Using an inverted microscope (Leica DMIL), small species were counted at $400 \times$ magnification until at least 400 cells were identified, whereas for large species one third $(1 \mathrm{~mL})$ of the complete chamber $(3 \mathrm{~mL})$ was counted at $100 \times$ magnification. Counting grids were distributed randomly over the whole counting chamber.

The obtained data were used to calculate biovolume for each species on each sampling day. Further, total biovolume and biodiversity were calculated. The Shannon-Index was chosen as an indicator for biodiversity because it considers number as well as evenness of species (Purves et al., 2001; Washington, 1984).

$\mathrm{H}^{\prime}=-\sum$ pi ln (pi) with $\quad$ pi $=\frac{\mathrm{n}_{\mathrm{i}}}{\mathrm{N}}$

$\mathrm{H}^{\prime}$ is the abundance based and $\mathrm{HB}^{\prime}$ the biovolume based diversity index, pi represents the relative importance of species $i, n_{i}$ is the abundance of species $\mathrm{i}$, and $\mathrm{N}$ the total abundance of all species (Washington, 1984).

Growth rates for total biovolume as well as for individual species were calculated according to: $\mu=\frac{\ln \left(\mathrm{B}_{2}\right)-\ln \left(\mathrm{B}_{1}\right)}{\mathrm{t}_{2}-\mathrm{t}_{1}}$

$\mu$ represents the specific growth rate per day whereas $t_{1}$ and $t_{2}$ are specific points in time during the experiment and $\mathrm{B}_{1}$ and $\mathrm{B}_{2}$ indicate the respective biovolume.

Total biovolume loss or gain and post stress community growth rates were calculated as measures of resistance and resilience. Resistance was equivalent to the relative biovolume loss or gain at day 19 (when the stressor regime had ended), calculated as the percentage biovolume that was lost (or gained) in every treatment compared to the control treatment $\left(18{ }^{\circ} \mathrm{C}\right.$, no sediment). Resilience, expressed as post stress community growth rate, was calculated for the final 10 days (day 19-29), the recovery phase of the experiment.

To assess species performance under stress (day 5-19) and during recovery (day 19-29), we additionally calculated individual growth rates for these time periods.

\subsection{Analysis of cumulative stressor effects}

To assess whether or not the combined effects of temperature and turbidity during the two heat waves were additive, we applied the additive effects model to community resistance (biovolume loss or gain) and biodiversity $\left(\mathrm{H}^{\prime}\right)$ at the end of the stressor application. This model has been described as particularly suitable when stressors affect different physiological processes (Folt et al., 1999), which is the case for heat waves (Boyd et al., 2010) and aspects of turbidity (Zehrer et al., 2015). According to this model, multiple stressors affect organisms synergistically when the observed effect of the combined stressors is greater than predicted from the sum of single stressor effects. If the observed effect is smaller than the sum of single stressor effects, the multiple stressors effect is antagonistic (Folt et al., 1999; Hay et al., 1994).

\subsection{Statistical analysis}

Two-factorial repeated measures analyses of variance (ANOVA) were conducted to test the effects of temperature and turbidity over time on community biovolume and biodiversity, as well as separately for cryptophyceae and chlorophyceae. The repeated measures analysis included three cardinal time points: after the initial growth phase, after the phase with the stressor regime and after the recovery phase. Stressor effects on resistance (biovolume loss after stress application) and resilience (recovery growth rate) were examined using a two-factorial ANOVA. Biovolume data were log-transformed, diversity $\left(\mathrm{H}^{\prime}\right)$ data were squared and the percentage of cryptophyceae + green algal biovolume was square root transformed after Freeman and Tukey (1950). The Cochran C test was applied to test the homogeneity of variances. To detect significant differences between different levels within single treatments, Tukey's HSD was used as posthoc-test. Effects were considered significant at $\mathrm{p}<0.05$.

\section{Results}

\subsection{Community resistance and resilience regarding biovolume development}

Corresponding to an overall decrease in nutrients (Fig. 2), total biovolume increased over the course of the experiment (Fig. 3). Three days after stressor application (day 8), community biovolume was still low (Fig. 3) and nutrient concentrations (N, P, to a lesser extent also Si) were higher in turbid treatments than in corresponding clear treatments, indicating that nutrients were added with the sediment. Although initially all nutrients were available in high concentrations, nitrogen was strongly reduced after 15 days in all treatments (down to 4.9 بmol/L; Fig. 2).

Increasing temperature significantly decreased total biovolume 

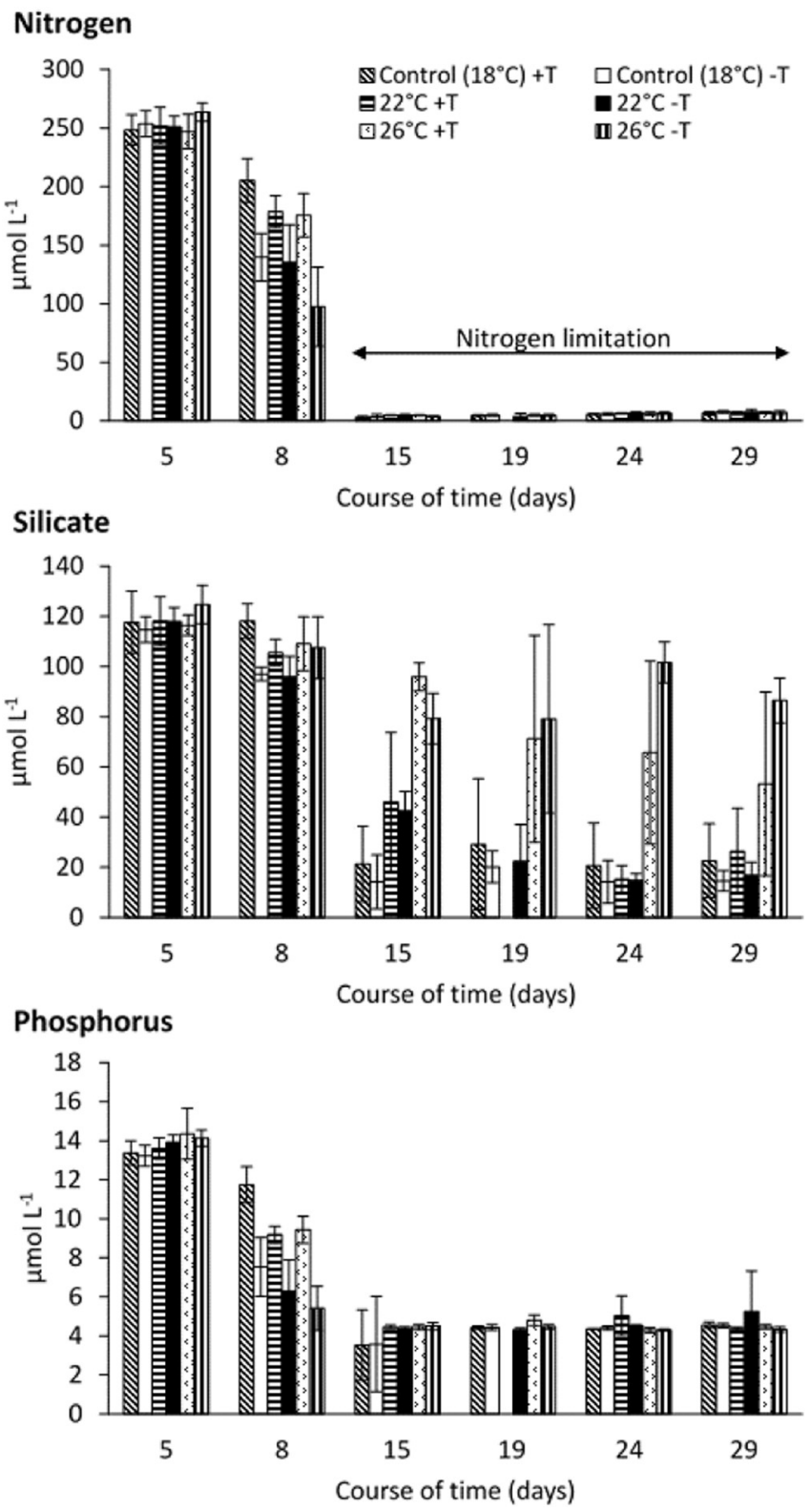

Fig. 2. Nutrient content of every treatment over the course of the experiment $(\mu \mathrm{mol} / \mathrm{L}$; average $\pm \mathrm{SD}$ ). Data for $22^{\circ} \mathrm{C}+\mathrm{T}$ on day 19 did not conform with all other data and was therefore excluded.

(rmANOVA, significant temperature main effect, $\mathrm{p}<0.01$, Table 1 ). Whereas the biovolume differed non-significantly between the control temperature and $22{ }^{\circ} \mathrm{C}$ heat wave, the difference was significant between the $26^{\circ} \mathrm{C}$ and both the control and the $22^{\circ} \mathrm{C}$ heat wave (Tukey HSD, $\mathrm{p}<0.01$ ). Biovolume increase over time at $26^{\circ} \mathrm{C}$ was lower than in the control and at $22^{\circ} \mathrm{C}$ (rmANOVA, significant 2-way interaction, $\mathrm{p}<0.05$, Table 1 ), suggesting that temperature effects mitigated the biovolume increase in the $26^{\circ} \mathrm{C}$ heat wave but not the $22{ }^{\circ} \mathrm{C}$ heat wave treatment.

Turbidity, by contrast, increased total biovolume. The turbidity effect was, however, marginally non-significant (rm ANOVA, main effect, $\mathrm{p}=0.069$, Table 1). Neither the interaction between subjects with temperature nor the interaction with time within subjects was significant.

When separating the response of biovolume into a resistance and resilience aspect, the stressor application affected the experimental communities with respect to both, loss and recovery. Biovolume loss was highest (68\%), i.e., resistance was lowest, during the $26^{\circ} \mathrm{C}$ heat wave without turbidity (Table 2), whereas loss of biovolume was less severe in the clear $22{ }^{\circ} \mathrm{C}$ heat wave treatment (9\%). In turbid treatments, biovolume loss was less severe than in clear treatments (turbid $26{ }^{\circ} \mathrm{C}$ heat wave) or biovolume was gained (turbid $22{ }^{\circ} \mathrm{C}$ heat wave and $18{ }^{\circ} \mathrm{C}$ control). Consequently, we found significant main temperature effects and a significant temperature $\mathrm{x}$ turbidity interaction on resistance at day 19 (Table 3).

Recovery growth rates were positive in the $26^{\circ} \mathrm{C}$ treatments, whereas no further growth was observed for the control and non-significant positive growth rates at $22{ }^{\circ} \mathrm{C}$ (Table 2). Still, neither temperature nor turbidity had significant impacts on recovery (Table 3 ).

\subsection{Phytoplankton diversity}

The diversity index $\mathrm{H}^{\prime}$ was affected by turbidity (Fig. 4, rmANOVA, significant turbidity main effect, $\mathrm{p}<0.01$, Table 1 ). As a result, $\mathrm{H}^{\prime}$ in turbid treatments was significantly higher than in treatments without turbidity (Tukey HSD $<0.01$ ). The effect of temperature on $\mathrm{H}^{\prime}$ was not significant. However, a significant 2-way interaction between turbidity and temperature ( $\mathrm{rm}$ ANOVA, $\mathrm{p}<0.05$, Table 1 ) reflected that $\mathrm{H}^{\prime}$ in turbid control $\left(18^{\circ} \mathrm{C}\right)$ and $22^{\circ} \mathrm{C}$ heat wave treatments was higher than in the respective clear treatments $\left(18^{\circ} \mathrm{C}\right.$ and $\left.22^{\circ} \mathrm{C}\right)$, while under the influence of the $26^{\circ} \mathrm{C}$ heat wave $\mathrm{H}^{\prime}$ in the turbid treatment was lower than in the clear treatment. While $\mathrm{H}^{\prime}$ remained on a high level in the turbid control $\left(18^{\circ} \mathrm{C}\right)$ and the turbid $22^{\circ} \mathrm{C}$ heatwave (Fig. 4A), it declined steadily over time in the control and the $22^{\circ} \mathrm{C}$ heat wave treatment without turbidity (Fig. 4B). In contrast to this interaction, the time course of $\mathrm{H}^{\prime}$ remained very similar in turbid and clear treatments of the $26{ }^{\circ} \mathrm{C}$ heat wave (Fig. 4). In both, the turbid and the clear treatment, $\mathrm{H}^{\prime}$ decreased during the time the heat wave was applied, and levelled off (turbid treatment, Fig. 4A) or increased again (clear treatment, Fig. 4B) during the recovery phase (rmANOVA, significant 3-way interaction, $\mathrm{p}<0.01$, Table 1 ).

\subsection{Group-specific response}

Community composition developed similarly in all treatments before the stressor regime was applied on day 5 (Fig. 5). Initially, the experimental community consisted of $60 \%$ diatom, $20 \%$ dinoflagellate, $10 \%$ chlorophyceae, and $10 \%$ cryptophyceae biovolume. On day five, cryptophyceae and chlorophyceae together contributed $65-70 \%$ of the total biovolume in all treatments, and the percentage of diatoms and dinoflagellates had declined. The percentage of dinoflagellate biovolume continued declining and was virtually undetectable after the first half of the stressor application. From day 5 on, the proportion of diatom biovolume increased again, and chlorophyceae and cryptophyceae decreased in the control $\left(18^{\circ} \mathrm{C}\right.$ ) (Fig. 5D) and in clear and turbid $22^{\circ} \mathrm{C}$ treatments (Fig. 5B, E). In $26^{\circ} \mathrm{C}$ treatments with and without turbidity (Fig. 5C, F) percent green algal and cryptophyte biovolume increased during the stressor regime, and remained on a high level throughout the recovery phase (rmANOVA, significant temperature main effect, $\mathrm{p}<0.01$, Table 1 ). While percent green algal and cryptophyte biovolume did not differ significantly in control and $22^{\circ} \mathrm{C}$ heat wave treatment, the percentage of these algal groups was significantly higher in the $26^{\circ} \mathrm{C}$ treatment than in the control and at $22^{\circ} \mathrm{C}$ (Tukey HSD, $\mathrm{p}<0.01)$. Turbidity mitigated the temperature effect. In turbid $18^{\circ} \mathrm{C}$ (Fig. 5A) and $22^{\circ} \mathrm{C}$ (Fig. 5B) treatments, the percentage of chlorophyceae and cryptophytes decreased to a lesser degree, and in the turbid $26^{\circ} \mathrm{C}$ treatment (Fig. 5C) the increase of the percentage of these algal groups was less pronounced than in their counterparts without turbidity (rmANOVA, significant 2-way interaction, $\mathrm{p}<0.01$, Table 1).

\subsection{Species-specific response}

Rhodomonas salina (cryptophyceae) and Chlamydomonas sp. 
Turbid

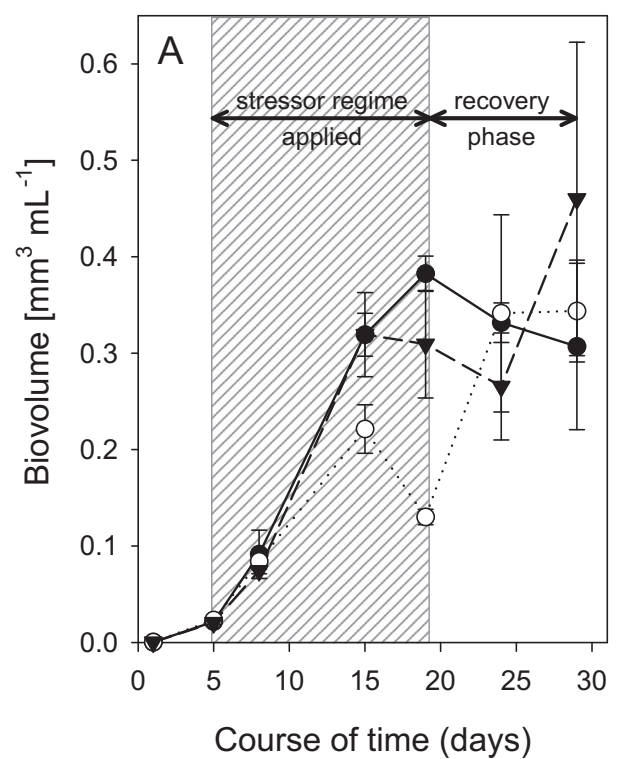

Clear

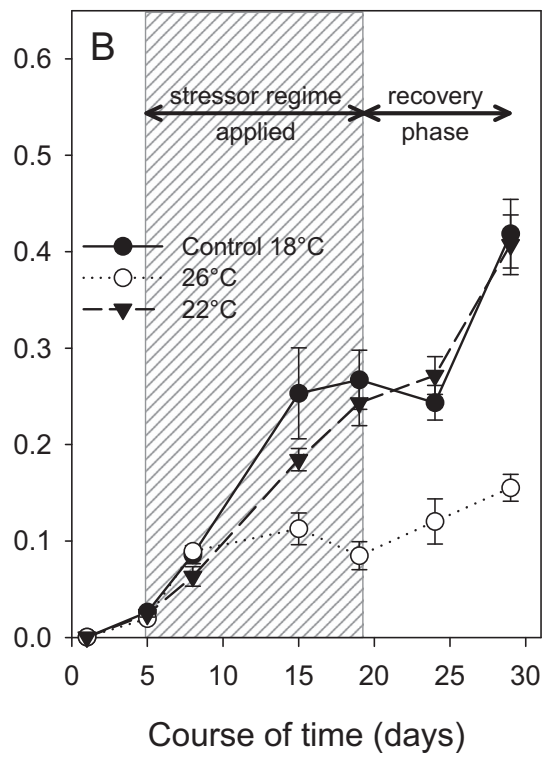

Fig. 3. Development of total biovolume of all treatments over the course of the experiment (30 days) (average total biovolume \pm SE). (A) shows the treatments with turbidity (heat waves and turbidity) and (B) without turbidity (heat waves only).

Table 1

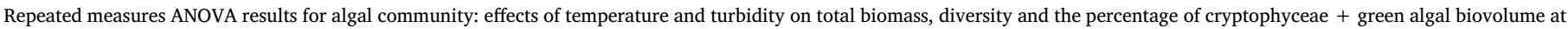

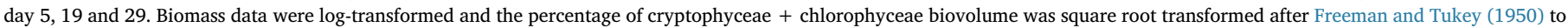

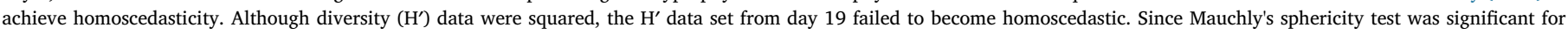

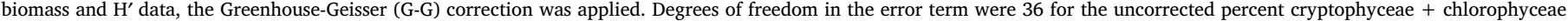
result, 20.42 after G-G correction for biomass and 25.76 after G-G correction for $\mathrm{H}^{\prime}$.

\begin{tabular}{|c|c|c|c|c|c|c|c|c|c|}
\hline \multirow[t]{2}{*}{ Effect } & \multirow[t]{2}{*}{$\mathrm{df}$} & \multicolumn{2}{|c|}{ Biomass } & \multirow[t]{2}{*}{ df } & \multicolumn{2}{|l|}{$\mathrm{H}^{\prime}$} & \multirow[t]{2}{*}{ df } & \multicolumn{2}{|c|}{$\%$ Cryptophyceae + Chlorophyceae } \\
\hline & & $F$ & $\mathrm{p}$ & & $F$ & $\mathrm{P}$ & & $F$ & $\mathrm{p}$ \\
\hline Temperature & 2 & 16.85 & 0.0001 & 2 & 1.193 & 0.3262 & 2 & 65.72 & 0.0000 \\
\hline Turbidity & 1 & 3.748 & 0.0688 & 1 & 121.4 & 0.0000 & 1 & 1.885 & 0.1866 \\
\hline Temperature* Turbidity & 2 & 1.767 & 0.1992 & 2 & 44.43 & 0.0000 & 2 & 12.14 & 0.0005 \\
\hline TIME & 1.13 & 74.16 & 0.0000 & 1.41 & 75.16 & 0.0000 & 2 & 6.800 & 0.0031 \\
\hline TIME* Temperature & 2.27 & 3.371 & 0.0491 & 2.86 & 4.671 & 0.0106 & 4 & 19.91 & 0.0000 \\
\hline TIME* Turbidity & 1.13 & 0.917 & 0.3621 & 1.41 & 27.66 & 0.0000 & 2 & 0.418 & 0.6614 \\
\hline TIME* Temperature* Turbidity & 2.27 & 1.845 & 0.1802 & 2.86 & 13.48 & 0.0000 & 4 & 2.374 & 0.0703 \\
\hline
\end{tabular}

Table 2

Biovolume loss or gain after the stressor regime (day 19) and recovery growth rate (day 19-29). Average of total biovolume ( \pm SD).

\begin{tabular}{lll}
\hline Treatment & $\begin{array}{l}\text { Biovolume loss or gain day } 19 \\
(\%)\end{array}$ & $\begin{array}{l}\text { Recovery growth rate day } \\
29\end{array}$ \\
\hline Control clear & $\pm 0(23)$ & $0.046(0.027)$ \\
Control turbid & $+43.11(13.7)$ & $-0.035(0.052)$ \\
$22{ }^{\circ} \mathrm{C}$ clear & $-9.03(22.67)$ & $0.052(0.042)$ \\
$22{ }^{\circ} \mathrm{C}$ turbid & $+15.73(41.76)$ & $0.012(0.141)$ \\
$26{ }^{\circ} \mathrm{C}$ clear & $-68.28(10.9)$ & $0.063(0.016)$ \\
$26{ }^{\circ} \mathrm{C}$ turbid & $-51.31(6.01)$ & $0.095(0.04)$ \\
\hline
\end{tabular}

(chlorophyceae) showed positive growth rates in all treatments throughout the stressor application (Fig. 12A, B). Highest growth rates were reached at $26^{\circ} \mathrm{C}$ for both species, and growth rates were higher in turbid than in clear heat wave treatments and controls. During the recovery phase, however, $R$. salina continued growing only in the $26^{\circ} \mathrm{C}$ heat wave treatment without turbidity and Chlamydomonas sp. grew in the turbid $22{ }^{\circ} \mathrm{C}$ heat wave treatment and in both $26^{\circ} \mathrm{C}$ treatments.

Within the group of diatoms (Fig. 6C), Cylindrotheca closterium reached noticeably higher growth rates in the clear control $\left(18^{\circ} \mathrm{C}\right)$ and during the $22^{\circ} \mathrm{C}$ heat wave than in their turbid counterparts, but did not grow when affected by the $26^{\circ} \mathrm{C}$ heat wave. During the recovery phase $C$. closterium continued growing in all treatments except in the
Table 3

Factorial ANOVA results for algal communities: effects of temperature and turbidity on biomass loss after the stressor regime (day 19) and on recovery growth rate (day 29). Data for biomass loss day 19 were squared to achieve homoscedasticity. Data for the recovery growth rate were $Y^{\prime}=(1 / Y+1)$ transformed, however homoscedasticity could not be achieved.

\begin{tabular}{lllllll}
\hline \multirow{2}{*}{ Effect } & df & \multicolumn{2}{l}{ Biomass loss day 19} & & \multicolumn{2}{l}{ Recovery growth rate } \\
\cline { 3 - 4 } & & $F$ & $\mathrm{p}$ & & $F$ & $\mathrm{p}$ \\
\hline Temperature & 2 & 19.37 & 0.000 & & 2.095 & 0.152 \\
Turbidity & 1 & 0.256 & 0.619 & & 1.568 & 0.227 \\
Temperature*Turbidity & 2 & 8.567 & 0.002 & & 1.263 & 0.307 \\
\hline
\end{tabular}

turbid $26^{\circ} \mathrm{C}$ heat wave, where it was lost from the community. Consequently, this species dominated control and $22^{\circ} \mathrm{C}$ heat wave treatments at the end of the experiment. During the stressor application, Leptocylindrus danicus grew in control $\left(18^{\circ} \mathrm{C}\right)$ treatments with and without turbidity and in turbid $22^{\circ} \mathrm{C}$ and $26^{\circ} \mathrm{C}$ heat wave treatments. In the recovery phase this species continued growing in turbid $22{ }^{\circ} \mathrm{C}$ and $26^{\circ} \mathrm{C}$ heat wave treatments and showed recovery growth in the $26^{\circ} \mathrm{C}$ heat wave treatment without turbidity. Coscinodiscus granii and Pseudonitzschia sp. grew only in turbid treatments during the stressor application (control $18{ }^{\circ} \mathrm{C}, 22^{\circ} \mathrm{C}$ and $26^{\circ} \mathrm{C}$ heat wave treatments), and did not grow during the recovery phase. Thalassiosira sp. grew in the 


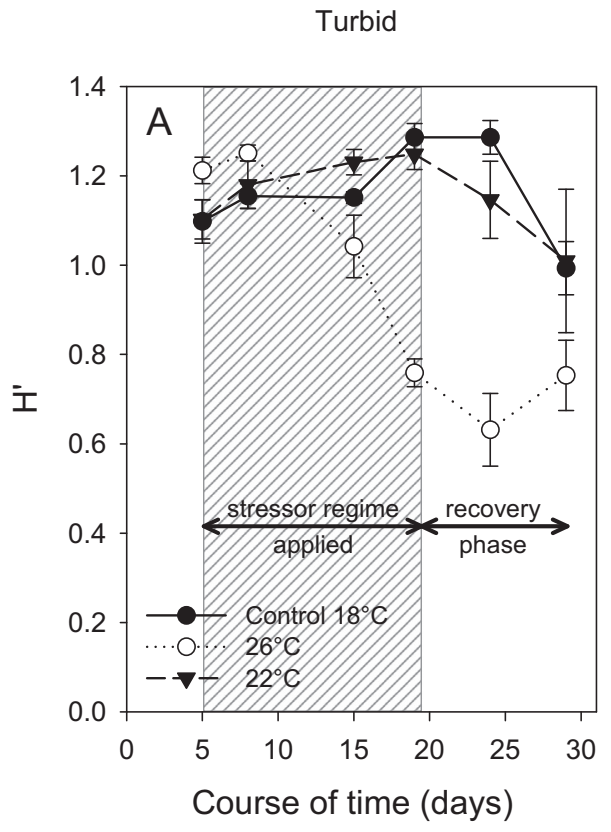

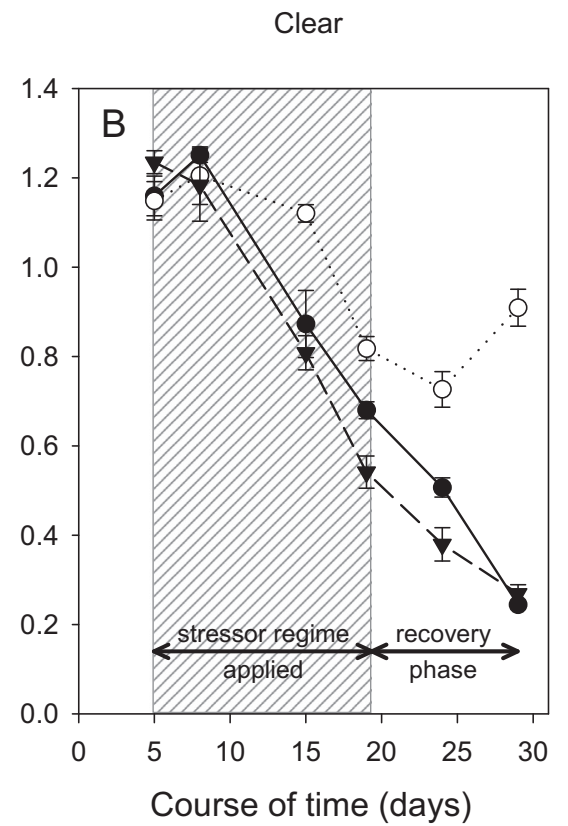

Fig. 4. Diversity of the experimental communities in the course of the experiment. (A) Diversity index $\left(\mathrm{H}^{\prime}\right)$ in turbid treatments (heat waves and turbidity), (B) $\mathrm{H}^{\prime}$ in clear treatments (heat waves only). Error bars denote the standard error. Note the difference in scaling. control $\left(18^{\circ} \mathrm{C}\right)$ treatments with and without turbidity but ceased growing during the recovery phase.

Throughout the experiment, the dinoflagellates Scrippsiella trochoidae and Prorocentrum micans did not show positive growth rates in the control or any of the heat wave treatments (Fig. 6D).

\subsection{Cumulative effects of multiple stressors}

The observed combined effect of the $22{ }^{\circ} \mathrm{C}$ heat wave plus turbidity on community stability in our experiment was a gain in biovolume, which was smaller than predicted from the sum of single stressor effects. The combined effect was antagonistic according to the additive model (Table 4). For the stressor combination $26^{\circ} \mathrm{C}$ heat wave plus turbidity a biovolume loss was predicted. The combined effect observed was larger than predicted, and therefore synergistic according to the additive model.

The combined effect of $22{ }^{\circ} \mathrm{C}$ heat wave plus turbidity on biodiversity was observed to be positive and higher than predicted based on single stressor effects. According to the additive model this effect was synergistic. For the combination $26^{\circ} \mathrm{C}$ heat wave and turbidity, the observed effect was positive and smaller than predicted, so this combined effect was antagonistic (Table 4). This illustrates that combined effects of heat waves and turbidity on stability and biodiversity are nonadditive and cannot be extrapolated from studies investigating the effects of single stressors.

\section{Discussion}

\subsection{Resistance and resilience to heat waves}

Community responses to the heat waves differed between the two temperature regimes applied. A medium heat wave of $22^{\circ} \mathrm{C}$, with the temperature being $4{ }^{\circ} \mathrm{C}$ above the control with average summer temperature $\left(18{ }^{\circ} \mathrm{C}\right)$ had a perceptible but small impact on the algal community. A further $4{ }^{\circ} \mathrm{C}$ temperature increase $\left(26^{\circ} \mathrm{C}\right)$ resulted in notably stronger effects.

In the control $\left(18^{\circ} \mathrm{C}\right)$ community biovolume increased over time. As in all treatments, the biovolume composition changed within the first five days from mainly diatoms $(60 \%)$ to mainly small flagellates (Rhodomonas salina and Chlamydomonas sp.), which together contributed about $70 \%$ of the community biovolume. Such small species are known to react with high growth rates if nutrient supply is high (Sommer, 1989). Being able to out-compete other species under nitrogen limitation (Harrison and Davis, 1979), C. closterium dominated the experimental community at the end of the experiment. The biodiversity index $\left(\mathrm{H}^{\prime}\right)$ declined from day eight, when nutrients were still abundant, and reached a low level at the end of the experiment although except for Chaetoceros sp. all species were still present in low numbers.

Community development during the $22^{\circ} \mathrm{C}$ heat wave remained similar to the control. Resistance to the heat wave was high, as only a small percentage of biovolume was lost, and the community recovered quickly. At the end of the experiment, the community biovolume of the $22{ }^{\circ} \mathrm{C}$ heat wave treatment was on the same level as that of the control. C. closterium carried the recovery and, as in the $18^{\circ} \mathrm{C}$ control, dominated the community at the end of the experiment. The community response to the $22{ }^{\circ} \mathrm{C}$ heat wave is consistent with experimental stability studies that found resilience to be related to the dominance of fast growing species (Steiner et al., 2005, 2006). Due to the differences in the performance of two diatom species, $\mathrm{H}^{\prime}$ during the $22^{\circ} \mathrm{C}$ heat wave and the recovery phase was slightly lower than in the control. In contrast to the control where only one species was lost, six out of ten species vanished in the $22{ }^{\circ} \mathrm{C}$ heat wave. The differences in biodiversity time course and species loss can be attributed to a faster competitive displacement of inferior species induced by a faster species turnover at higher temperatures (Brown et al., 2004; Burgmer and Hillebrand, 2011).

A further temperature increase by $4{ }^{\circ} \mathrm{C}$ affected the development of the algal community strongly. Resistance was low, since a large proportion of biovolume was lost during the $26^{\circ} \mathrm{C}$ heat wave. Similar to communities shifting from diatom to green algal domination due to increased water temperatures in the vicinity of power station discharge canals (Valiela, 2013), the percentage of small flagellates increased and dominated the community at the end of the $26{ }^{\circ} \mathrm{C}$ heat wave. $R$. salina and Chlamydomonas sp. grew faster at $26^{\circ} \mathrm{C}$ than in the control. $R$. salina is known to show increased growth rates at higher temperatures (Hammer et al., 2002). Chlamydomonas spp. have been shown to dominate phytoplankton communities at high temperatures (Burgmer and Hillebrand, 2011) and are able to withstand small short term heat waves of up to $39{ }^{\circ} \mathrm{C}$ (Seifert et al., 2015). The co-dominance of $R$. salina and Chlamydomonas sp. might point toward a relation between temperature and algal cell size. Due to their small size and considering the 


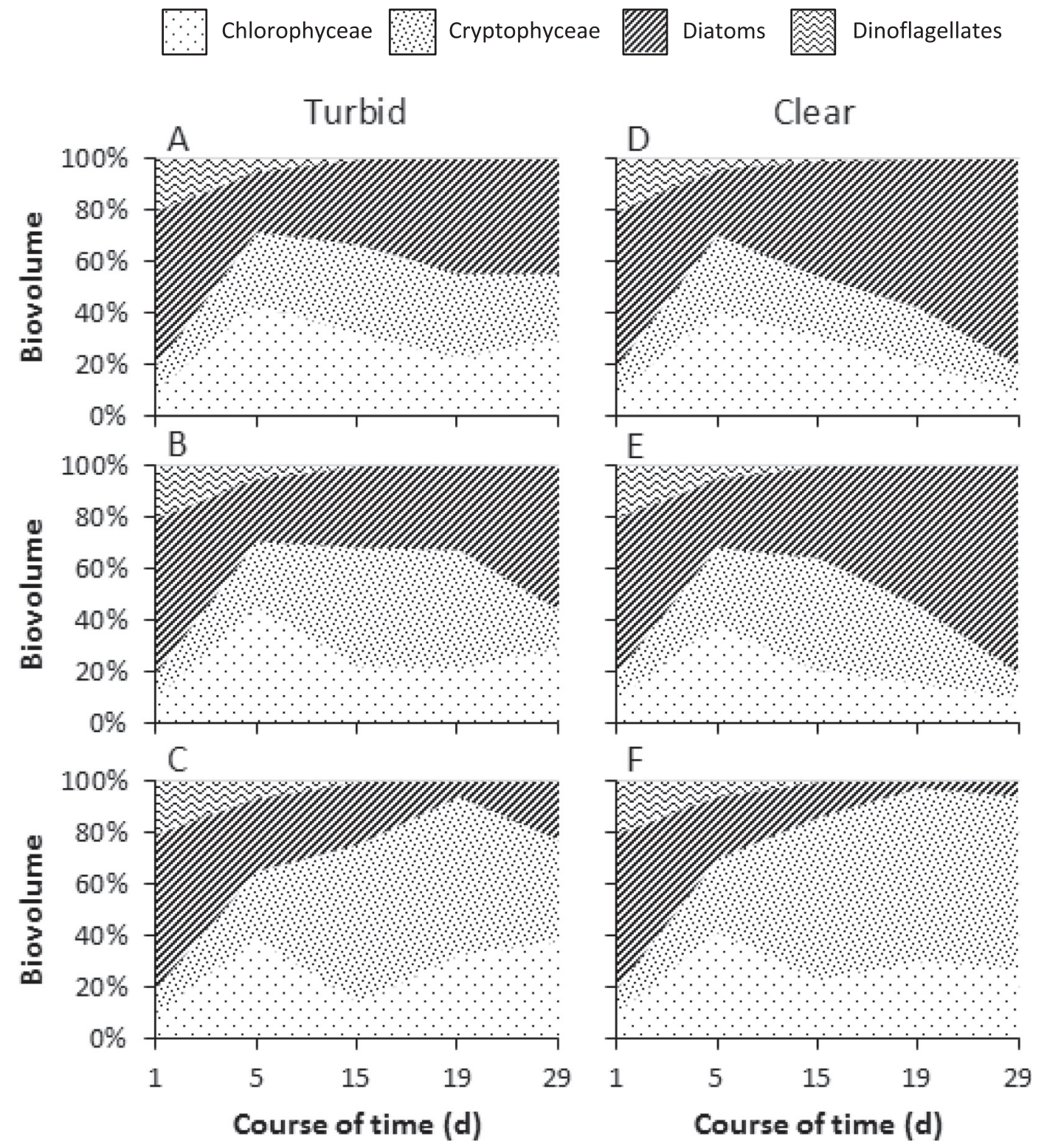

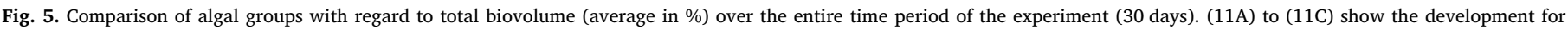

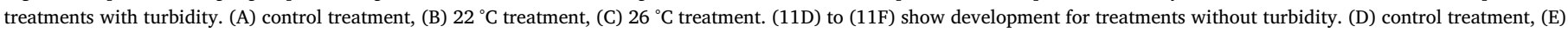
$22{ }^{\circ} \mathrm{C}$ treatment, (F) $26{ }^{\circ} \mathrm{C}$ treatment.

low nutrient content in the second half of the experiment, the small flagellates might have profited from a better nutrient uptake rate and a faster turnover in biovolume at high temperatures (Agawin et al., 2000; Burgmer and Hillebrand, 2011). Coscinodiscus granii, a diatom species with a wide temperature tolerance (Kraberg et al., 2010), grew very slowly. The strongest competitor in control and $22^{\circ} \mathrm{C}$ heat wave treatment, C. closterium, ceased growing during the $26^{\circ} \mathrm{C}$ heat wave. This corresponds to its temperature range of $10-25{ }^{\circ} \mathrm{C}$ (Ohgai et al., 1986). Due to C. closterium reverting to being a weak competitor and three species showing compensatory growth (Yachi and Loreau, 1999), $\mathrm{H}^{\prime}$ during the $26^{\circ} \mathrm{C}$ heat wave was higher than in the control. Four species were lost and did not re-occur. Resilience after the heat wave was low, as community biovolume recovered slowly. Recovery was not complete at the end of the experiment. Not only was community biovolume still considerably lower than in the control, the community was also still dominated by the small flagellates although diatom biovolume was increasing. Similar differences in algal community composition have been described for the recovery from short-term heat waves of high $\left(29^{\circ} \mathrm{C}\right.$ and $39^{\circ} \mathrm{C}$ ) intensity (Seifert et al., 2015). Obviously, resilience depended on how the traits that related to resistance and recovery were distributed within the community, which emphasises the importance of dominance structure (evenness) for community stability (Flöder and Hillebrand, 2012; Sasaki and Lauenroth, 2011).

\subsection{Effects of turbidity}

Turbidity applied as a single stressor (no heat wave) increased total biovolume and diversity. The suspended sediment evidentially brought in additional nutrients, which boosted algal growth particularly after day 15, when nitrogen concentrations were limiting. Resistance to turbidity was high, since biovolume was gained in the period the stressor was applied. The percentage of small flagellates decreased during stressor application, yet at a slower rate than in the control. This was due to several effects. Firstly, turbidity had a negative effect on the growth rate of $C$. closterium, which had shown the highest growth rates in the control during this time period. Secondly, the growth rates of $R$. salina and Chlamydomonas sp. were positively affected, and lastly four other diatom species also grew better in the treatment with turbidity 

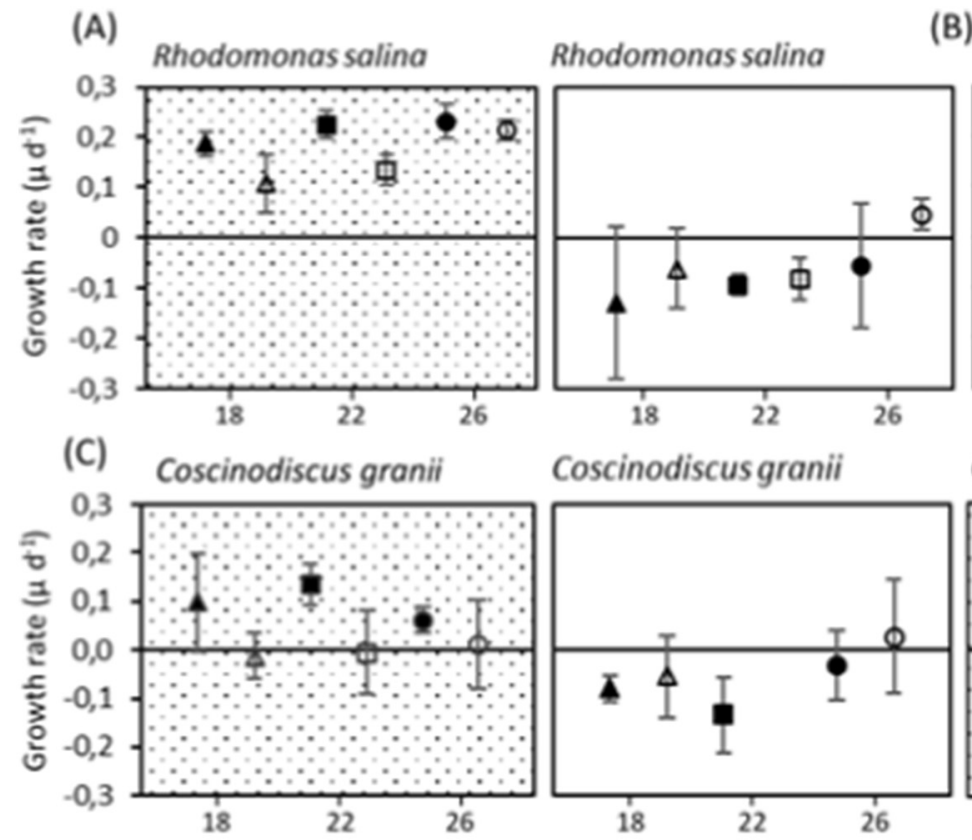

(B)

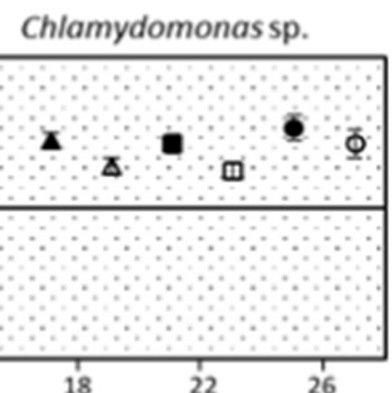

Chlamydomonas sp.

Coscinodiscus granii

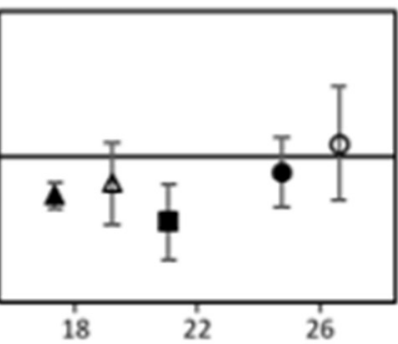

Cylindrotheca closterium
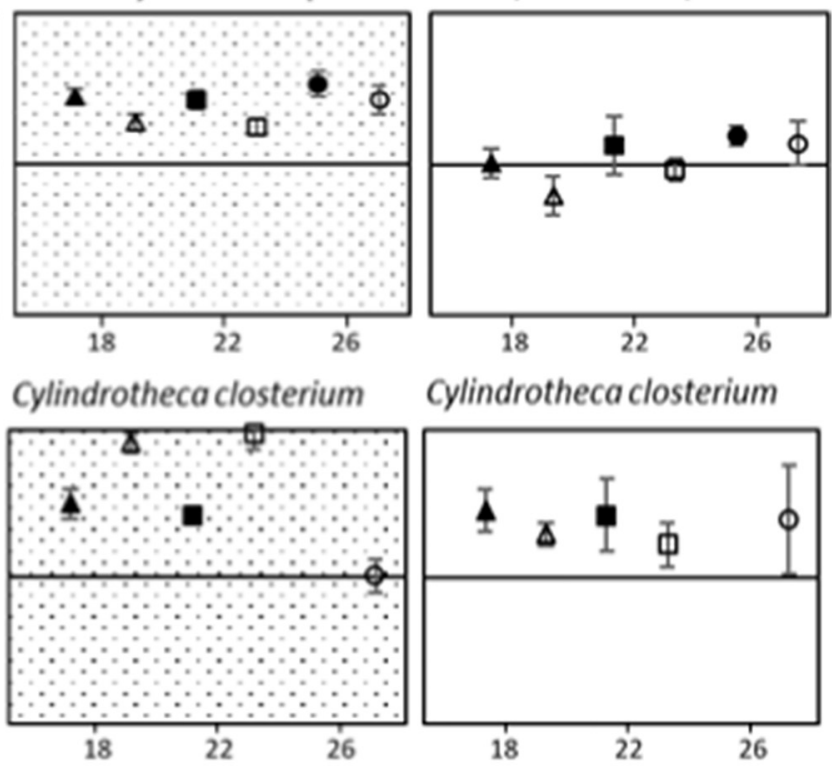

Cylindrotheca closterium

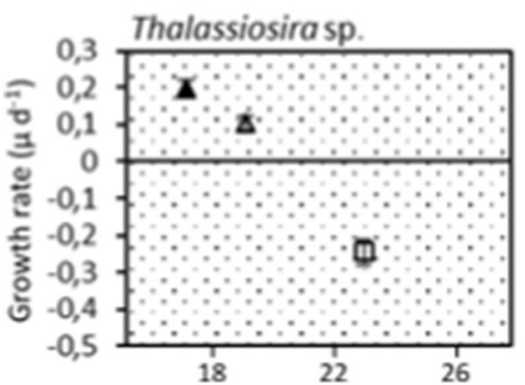

Thalassiosirasp.

Pseudonitzschiasp.
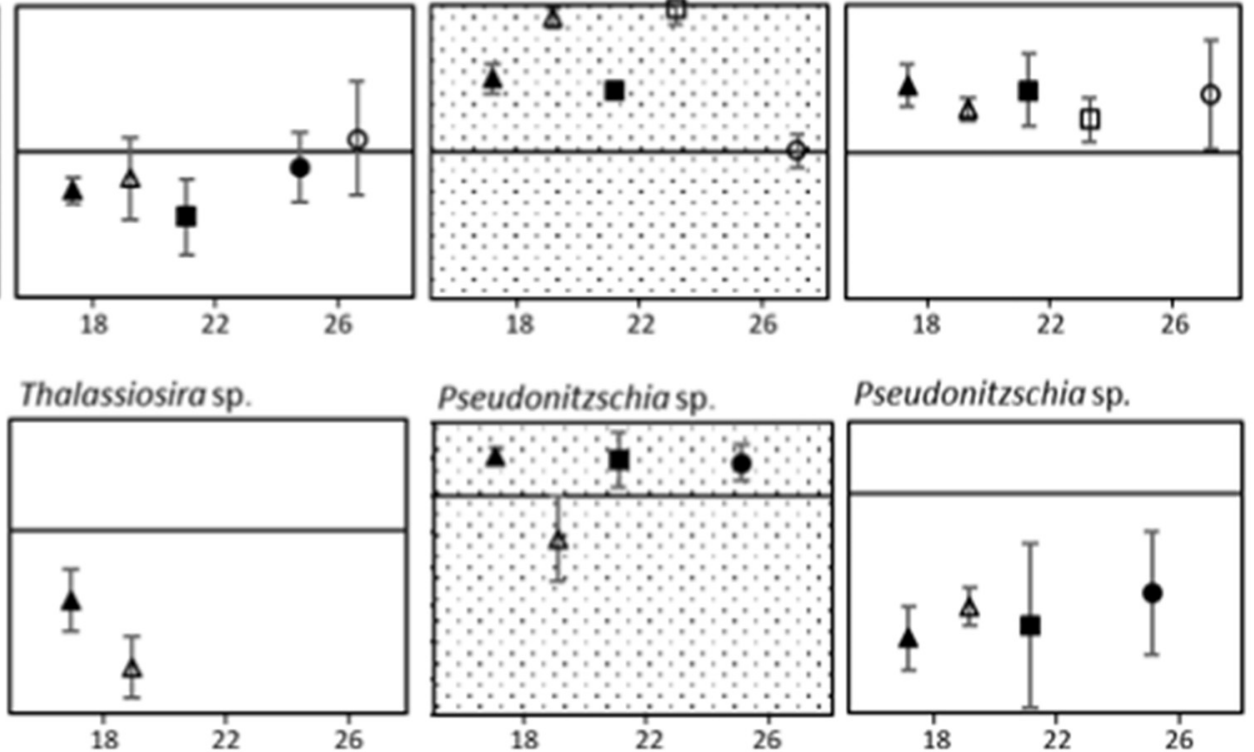

Pseudonitzschiasp.

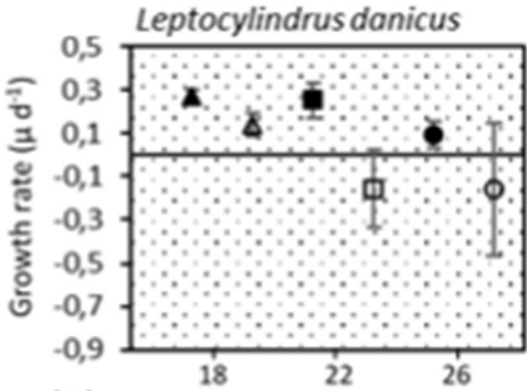

Leptocylindrus danicus
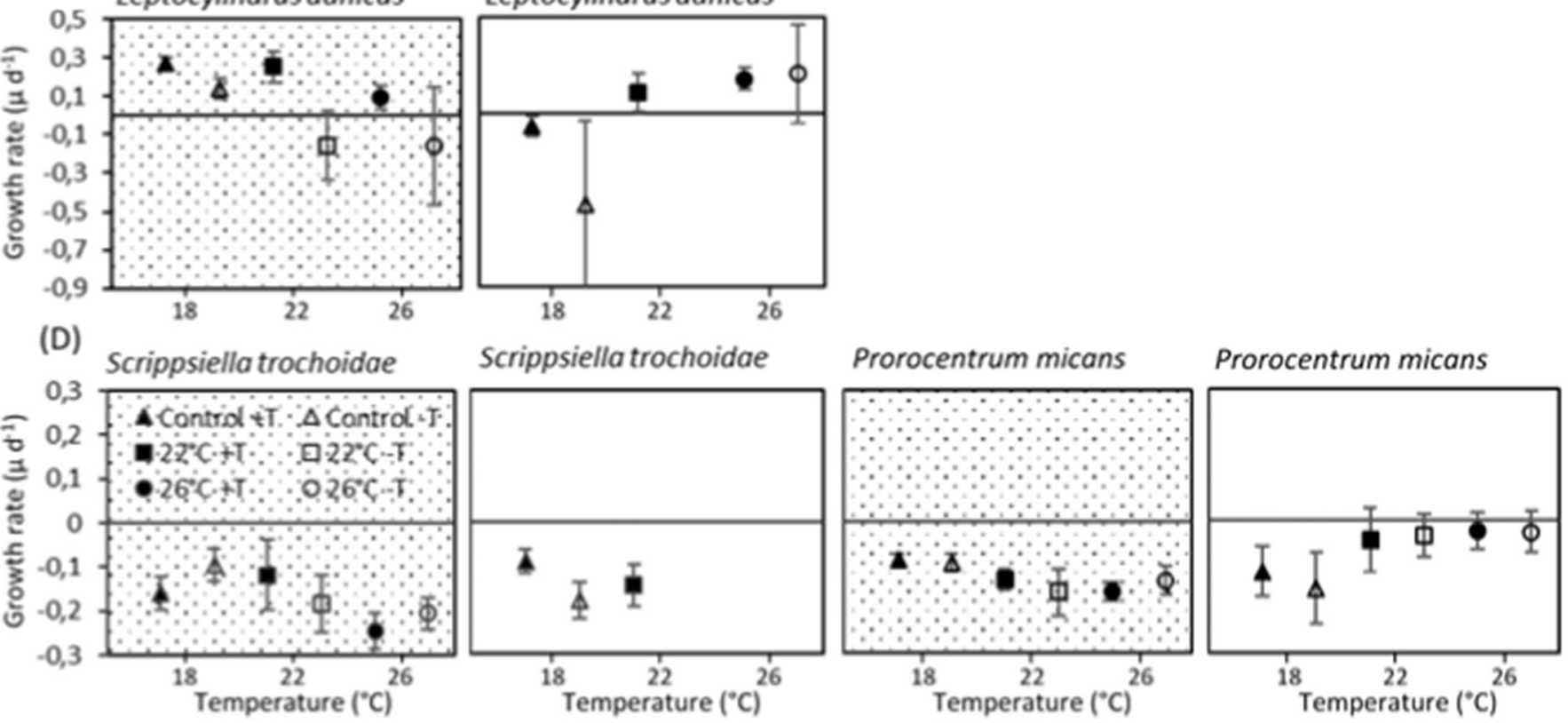

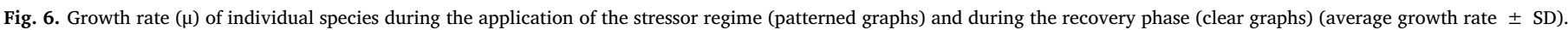

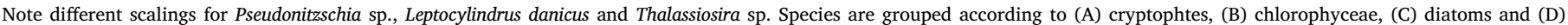

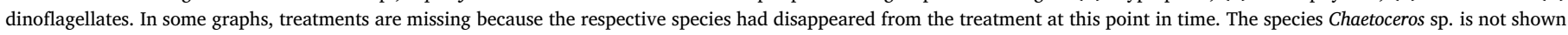
because no individuals were found after day 8 . 
Table 4

Synergistic and antagonistic interactions of turbidity (T) and heat waves according to the additive model. Calculations are based on percent biovolume loss or gain (Table 2) at the end of stressor regime (day 19), and on biodiversity index (see Fig. 4) after the stressor regime (day 19) in relation to the control $18{ }^{\circ} \mathrm{C}$ treatment. Control $18{ }^{\circ} \mathrm{C}: \mathrm{H}^{\prime}=0.68$ ( \pm 0.04$)$, Control $18{ }^{\circ} \mathrm{C}+\mathrm{T}: \quad \mathrm{H}^{\prime}=1.29 \quad( \pm 0.06), \quad 22^{\circ} \mathrm{C}: \quad \mathrm{H}^{\prime}=0.54 \quad( \pm 0.07)$, $22{ }^{\circ} \mathrm{C}+\mathrm{T}: \mathrm{H}^{\prime}=1.25( \pm 0.07), 26{ }^{\circ} \mathrm{C}: \mathrm{H}^{\prime}=0.82( \pm 0.05), 26{ }^{\circ} \mathrm{C}+\mathrm{T}: \mathrm{H}^{\prime}=0.76$ $( \pm 0.05)$.

\begin{tabular}{|c|c|c|c|c|}
\hline \multirow[t]{2}{*}{ Stressor } & \multirow{2}{*}{$\begin{array}{l}\text { Single stressor } \\
\text { effects }\end{array}$} & \multicolumn{2}{|c|}{ Cumulative effects } & \multirow[t]{2}{*}{ Interaction } \\
\hline & & Pred. & Obs. & \\
\hline \multicolumn{5}{|c|}{ Biovolume loss or gain (\%) } \\
\hline $\mathrm{T}$ & +43.11 & & & \\
\hline $22{ }^{\circ} \mathrm{C}$ & -9.03 & & & \\
\hline $\mathrm{T}+22^{\circ} \mathrm{C}$ & $+43.11-9.03$ & +34.08 & +15.73 & $\begin{array}{l}\text { Antagonistic (positive } \\
\text { effect weakened) }\end{array}$ \\
\hline $26^{\circ} \mathrm{C}$ & -68.28 & & & \\
\hline $\mathrm{T}+26^{\circ} \mathrm{C}$ & $+43.11-68.28$ & -25.15 & -51.31 & $\begin{array}{l}\text { Synergistic (negative } \\
\text { effect intensified) }\end{array}$ \\
\hline \multicolumn{5}{|c|}{ Diversity index $\left(\mathrm{H}^{\prime}\right)$} \\
\hline $\mathrm{T}$ & +0.61 & & & \\
\hline $22{ }^{\circ} \mathrm{C}$ & -0.14 & & & \\
\hline $\mathrm{T}+22{ }^{\circ} \mathrm{C}$ & $+0.61-0.14$ & +0.47 & +0.57 & $\begin{array}{l}\text { Synergistic (positive } \\
\text { effect intensified) }\end{array}$ \\
\hline $26^{\circ} \mathrm{C}$ & +0.14 & & & \\
\hline $\mathrm{T}+26^{\circ} \mathrm{C}$ & $+0.61+0.14$ & +0.75 & +0.08 & $\begin{array}{l}\text { Antagonistic (positive } \\
\text { effect weakened) }\end{array}$ \\
\hline
\end{tabular}

than in the clear control. Consequently, $\mathrm{H}^{\prime}$ increased slightly. In the control C. closterium dominated the experimental community at the end of the experiment, indicating that this species was the best competitor for nitrogen, which is supported by a study on nutrient competition in natural phytoplankton communities (Harrison and Davis, 1979). Although the suspended sediment most likely affected light availability in the experimental communities negatively, it is unlikely that the reduced growth rate of $C$. closterium was a result of light limitation. C. closterium, growing at light intensities as low as $0.5 \mu \mathrm{mol}$ photons $\mathrm{m}^{-2} \mathrm{~s}^{-1}$, is able to reach growth rates above the ones that we determined for the control treatment (Schlie et al., 2011). If the increased nutrient supply released the other phytoplankton species from nutrient limitation, and if these were able to utilise nitrogen faster than $C$. closterium, this would explain why the growth of $C$. closterium slowed down. Our results are supported by the results of an experimental study on the effects of sediment resuspension on phytoplankton that showed that the associated relief of nitrogen deficiency stimulated biomass and algal productivity in shallow coastal systems (Ogilvie and Mitchell, 1998), and by the results of a monitoring study on a brackish system, where the biovolume of some phytoplankton groups (cryptophyceae, diatoms, dinoflagellates) was positively correlated with turbidity (Zehrer et al., 2015).

\subsection{Resistance and resilience to the cumulative effects of heat wave and turbidity}

Instead of operating independently, the stressors heat wave and turbidity interacted and affected the phytoplankton communities nonadditively (Breitburg et al., 1998; Folt et al., 1999). We found significant interactions between the heat waves and turbidity for community resistance (biovolume loss or gain) and biodiversity $\left(\mathrm{H}^{\prime}\right)$. Resilience (community recovery growth), however, was affected neither by heat waves nor by turbidity.

Resistance of the algal community was high, when the $22{ }^{\circ} \mathrm{C}$ heat wave was combined with turbidity. In contrast to the $22{ }^{\circ} \mathrm{C}$ heat wave only treatment, biovolume was gained. Accordingly, turbidity alleviated the temperature effect on community stability during the $22^{\circ} \mathrm{C}$ heat wave. While the $22^{\circ} \mathrm{C}$ heat wave alone accelerated competitive exclusion due to faster species turnover at higher temperatures (Brown et al., 2004; Burgmer and Hillebrand, 2011), the exclusion process was slowed down during the turbid $22{ }^{\circ} \mathrm{C}$ heat wave. The proportion of small flagellates decreased to a much lesser extent and also diatoms were still abundant, which, despite the negative effect of turbidity on $C$. closterium, led to an increase in $\mathrm{H}^{\prime}$. This was due to nutrient desorption from the suspended sediment (Hamilton and Mitchell, 1997; Hansen et al., 1997) and the subsequent release of the phytoplankton species from nitrogen limitation, which responded with increased growth rates (Ogilvie and Mitchell, 1998).

The turbid $26^{\circ} \mathrm{C}$ heat wave affected the algal community strongly. Due to the mitigating effect of turbidity, resistance was slightly higher than in the $26^{\circ} \mathrm{C}$ heat wave only treatment. Similar to the turbid $22^{\circ} \mathrm{C}$ heat wave, sediment addition released several species from nitrogen limitation (Hamilton and Mitchell, 1997; Hansen et al., 1997; Ogilvie and Mitchell, 1998). C. closterium was lost during the turbid $26^{\circ} \mathrm{C}$ heat wave. With the best competitor for nitrogen missing from the community, recovery from the turbid $26^{\circ} \mathrm{C}$ heat wave was carried by Chlamydomonas sp. and from the diatoms C. granii, Pseudonitzschia sp. and $L$. danicus showing compensatory growth (Yachi and Loreau, 1999). In contrast to the other treatments, where the successful competitor $C$. closterium was still present, recovery remained incomplete at the end of the experiment. The permanent change in community composition that we observed in the turbid $26^{\circ} \mathrm{C}$ treatment is supported by other studies that have shown that multiple stressors can cause shifts in community composition (Segner et al., 2014; Vinebrooke et al., 2004).

\subsection{Synthesis and outlook: interactive effects of multiple stressors on marine phytoplankton communities}

\subsubsection{Single stressor effects (answering research question 1)}

Our study showed that the effect of heat waves on marine phytoplankton depends on the intensity of the heat wave. The moderate heat wave $\left(22^{\circ} \mathrm{C}\right)$ affected community stability slightly. A small proportion of biovolume was lost, competitive exclusion was accelerated, and biodiversity was negatively affected. The $26^{\circ} \mathrm{C}$ heat wave, in contrast, affected community stability substantially. A large proportion of biovolume was lost and biodiversity was positively affected. The successful competitor in control $\left(18{ }^{\circ} \mathrm{C}\right)$ and during the $22^{\circ} \mathrm{C}$ heat wave (Cylindrotheca closterium) ceased growing, compensatory growth of other species became important (see: Grime, 1998; Walker et al., 1999; Yachi and Loreau, 1999), and species composition shifted from diatom to small flagellate domination (Rhodomonas salina, Chlamydomonas sp.). Turbidity applied as a single stressor slowed the competitive replacement by releasing species from resource limitation via nutrient desorption (Ogilvie and Mitchell, 1998), and increased biodiversity and biovolume production.

\subsubsection{Multiple stressor effects (answering research question 2)}

Turbidity mitigated the effect of heat waves on community stability. This effect was weaker in the intense than in the moderate heat wave, indicating that the mitigating effect of one stressor is influenced by the intensity of the other. Such mitigating effects of multiple stressors are known to occur in marine food webs (Breitburg and Riedel, 2005). Similar to the turbidity only treatment, species were released from resource limitation, biovolume was gained and biodiversity was positively affected during the $22^{\circ} \mathrm{C}$ heat wave with turbidity. Although less biovolume was lost in the $26^{\circ} \mathrm{C}$ heat wave with turbidity than without, and several species reacted with increased growth rates, community composition and biodiversity followed a pattern similar to the $26^{\circ} \mathrm{C}$ heat wave only treatment. In contrast to the $26^{\circ} \mathrm{C}$ heat wave only treatment, however, the successful competitor C. closterium was lost, and recovery was carried by compensatory growth of other species.

Our results support the hypothesis that the interdependence of stressor regime, species traits, and species richness determines which mechanisms stabilise natural communities. If dominant species remain the best performers regardless of disturbance, stability will depend on population dynamics of these dominant species. If disturbance or environmental change reverses the hierarchy of successful functional 
traits and dominant species become rare or lost, stability will depend on compensatory growth of rare species (Flöder and Hillebrand, 2012).

\subsubsection{Severity of the effects and recovery (answering research question 3)}

Communities in the $22{ }^{\circ} \mathrm{C}$ heat wave treatments, with and without turbidity, recovered within the duration of the experiment, whereas recovery was not complete in the treatment that applied turbidity as a single stressor and in turbid and clear $26^{\circ} \mathrm{C}$ heat wave treatments. Although we did not find significant treatment effects on resilience of the phytoplankton community, some aspects became evident when analysing at group and species level. Despite the community recovery growth rate being negative, the community of the turbidity only treatment would eventually have recovered as the successful competitor (C. closterium) was still growing. Stressor effects were severe in both, the turbid and the clear $26^{\circ} \mathrm{C}$ heat wave, as losses were large and community composition shifted from diatom to flagellate domination. An extrapolation based on the recovery rate of diatoms showed that diatoms in the $26^{\circ} \mathrm{C}$ heat wave only treatment would have reached the biovolume of the control community within 80 days. Diatom recovery would have been faster in the turbid $26^{\circ} \mathrm{C}$ heat wave treatment (10 days). Due to the loss of the successful competitor, however, community composition in this treatment had changed permanently.

Our results have shown that the impact of the stressors on a community can extend beyond the period of exposure (Breitburg and Riedel, 2005). Persistant effects of heat waves are likely to affect aquatic food webs negatively, because a decrease in community stability can influence the response of the phytoplankton to following stressors (Breitburg and Riedel, 2005). The 2003 heat wave in Europe had stronger effects on diatom communities that were already affected by other pollutants (Morin et al., 2015). With increasing frequency of heat waves, communities might not recover fast enough to withstand subsequent heat waves (Sorte et al., 2010). Yet, phytoplankton species themselves might react relatively fast to changing environmental conditions due to their short generation times and genetic as well as phenotypic adjustments (Poloczanska et al., 2013; Segner et al., 2014). Further, Vinebrooke et al. (2004) showed in their conceptual model that multiple stressor interactions can also provoke more resilient species and positive co-tolerance between them. However, these changes will probably always be accompanied by a loss of less resilient species, which will ultimately result in a decrease in biodiversity.

\section{References}

Agawin, N.S.R., Duarte, C.M., Agustí, S., 2000. Nutrient and temperature control of the contribution of picoplankton to phytoplankton biomass and production. Limnol. Oceanogr. 45, 591-600.

Behrenfeld, M.J., O'Malley, R.T., Siegel, D.A., McClain, C.R., Sarmiento, J.L., Feldman, G.C., Milligan, A.J., Falkowski, P.G., Letelier, R.M., Boss, E.S., 2006. Climate-driven trends in contemporary ocean productivity. Nature 444, 752-755.

Boyce, D.G., Lewis, M.R., Worm, B., 2010. Global phytoplankton decline over the past century. Nature 466, 591-596.

Boyd, P.W., Strzepek, R., Fu, F., Hutchins, D.A., 2010. Environmental control of openocean phytoplankton groups: now and in the future. Limnol. Oceanogr. 55, 1353-1376.

Breitburg, D.L., Riedel, G.F., 2005. Multiple Stressors in Marine Systems. Marine Conservation Biology: The Science of Maintaining the sea's Biodiversity. Island Press, Washington, DC, pp. 167-182.

Breitburg, D.L., Baxter, J.W., Hatfield, C.A., Howarth, R.W., Jones, C.G., Lovett, G.M., Wigand, C., 1998. Understanding effects of multiple stressors: ideas and challenges. In: Pace, M.L., Groffman, P.M. (Eds.), Successes, Limitations, and Frontiers in Ecosystem Science. Springer, Berlin, pp. 416-431.

Brown, J.H., Gillooly, J.F., Allen, A.P., Savage, V.M., W., G.B., 2004. Toward a methabolic theory of ecology. Ecology 85, 1771-1789.

Burgmer, T., Hillebrand, H., 2011. Temperature mean and variance alter phytoplankton biomass and biodiversity in a long-term microcosm experiment. Oikos 120, 922-933.

Burgmer, T., Hillebrand, H., Pfenninger, M., 2007. Effects of climate-driven temperature changes on the diversity of freshwater macroinvertebrates. Oecologia 151, 93-103.

Capuzzo, E., Stephens, D., Silva, T., Barry, J., Forster, R.M., 2015. Decrease in water clarity of the southern and central North Sea during the 20th century. Glob. Chang. Biol. 21, 2206-2214.

Dzialowski, A.R., Wang, S.-H., Lim, N.-C., Beury, J.H., Huggins, D.G., 2008. Effects of sediment resuspension on nutrient concentrations and algal biomass in reservoirs of the Central Plains. Lake and Reservoir Management 24, 313-320.

Field, C.B., Barros, V.R., Mach, K., Mastrandrea, M., 2014. Climate Change 2014: Impacts, Adaptation, and Vulnerability. (Contribution of working group II to the fifth assessment report of the intergovernmental panel on climate change).

Flöder, S., Hillebrand, H., 2012. Species traits and species diversity affect community stability in a multiple stressor framework. Aquat. Biol. 17, 197-209.

Folt, C.L., Chen, C.Y., Moore, M.V., Burnaford, J., 1999. Synergism and antagonism among multiple stressors. Limnol. Oceanogr. 44, 846-877.

Freeman, M.F., Tukey, J.W., 1950. Transformations related to the angular and the square root. The Annals of Mathematical Statistics 607-611.

Garrabou, J., Coma, R., Bensoussan, N., Bally, M., Chevaldonné, P., Cigliano, M., Diaz, D., Harmelin, J.G., Gambi, M.C., Kersting, D.K., et al., 2009. Mass mortality in Northwestern Mediterranean rocky benthic communities: effects of the 2003 heat wave. Glob. Chang. Biol. 15, 1090-1103.

Grime, J.P., 1998. Benefits of plant diversity to ecosystems: immediate, filter and founder effects. J. Ecol. 86, 901-910.

Guillard, R.R.L., 1975. Culture of phytoplankton for feeding marine invertebrates. In: Smith, W.L., Chantey, M.H. (Eds.), Culture of Marine Invertebrate Animals. Plenum Publishers, New York, pp. 29-60.

Guillard, R.R.L., Ryther, J.H., 1962. Studies of marine planktonic diatoms: I. Cyclotella nana Hustedt, and Detonula confervacea (Cleve) Gran. Can. J. Microbiol. 8, 229-239.

Hamilton, D.P., Mitchell, S.F., 1997. Wave-induced shear stresses, plant nutrients and chlorophyll in seven shallow lakes. Freshw. Biol. 38, 159-168.

Hammer, A., Schumann, R., Schubert, H., 2002. Light and temperature acclimation of Rhodomonas salina (Cryptophyceae): photosynthetic performance. Aquat. Microb. Ecol. 29, 287-296.

Hansen, P.S., Phlips, E.J., Aldridge, F.J., 1997. The effects of sediment resuspension on phosphorus available for algal growth in a shallow subtropical lake, Lake Okeechobee. Lake and Reservoir Management 13, 154-159.

Harrison, P.J., Davis, C.O., 1979. The use of outdoor phytoplankton continuous cultures to analyse factors influencing species selection. J. Exp. Mar. Biol. Ecol. 41, 9-23.

Hay, M.E., Kappel, Q.E., Fenical, W., 1994. Synergisms in plant defenses against herbivores: interactions of chemistry, calcification, and plant quality. Ecology 75, 1714-1726.

Hays, G.C., Richardson, A.J., Robinson, C., 2005. Climate change and marine plankton. Trends Ecol. Evol. 20, 337-344.

Hillebrand, H., Dürselen, C.D., Kirschtel, D., Pollingher, U., Zohary, T., 1999. Biovolume calculation for pelagic and benthic microalgae. J. Phycol. 35, 403-424.

Hobday, A.J., Alexander, L.V., Perkins, S.E., Smale, D.A., Straub, S.C., Oliver, E.C.J., Benthuysen, J.A., Burrows, M.T., Donat, M.G., Feng, M., et al., 2016. A hierarchical approach to defining marine heatwaves. Prog. Oceanogr. 141, 227-238.

Hooper, M.J., Ankley, G.T., Cristol, D.A., Maryoung, L.A., Noyes, P.D., Pinkerton, K.E., 2013. Interactions between chemical and climate stressors: a role for mechanistic toxicology in assessing climate change risks. Environ. Toxicol. Chem. 32, 32-48.

Hov, Ø., Cubasch, U., Fischer, E., Höppe, P., Iversen, T., Kvamstø, N.G., Kundzewicz, Z.W., Rezacova, D., Rios, D., Duarte Santos, F., 2013. Trends in Extreme Weather Events in Europe: Implications for National and European Union Adaptation Strategies.

de Jorge, V.N., van Beusekom, J.E.E., 1995. Wind- and tide-induced resuspension of sediment and microphytobenthos from tidal flats in the Ems estuary. Limnol. Oceanogr. 40, 776-778.

Kraberg, A., Baumann, M., Dürselen, C.-D., 2010. Coastal Phytoplankton: Photo Guide for Northern European Seas. Pfeil.

Lewandowska, A.M., Breithaupt, P., Hillebrand, H., Hoppe, H.G., Jürgens, K., Sommer, U., 2012. Responses of primary productivity to increased temperature and phytoplankton diversity. J. Sea Res. 72, 87-93.

Loewe, P., Klein, H., Weigelt-Krenz, S., 2013. System Nordsee-2006 \& 2007: Zustand und Entwicklungen. Berichte des BSH 49.

Meehl, G.A., Tebaldi, C., 2004. More intense, more frequent, and longer lasting heat waves in the 21st century. Science 305, 994-997.

Moore, J.A.Y., Bellchambers, L.M., Depczynski, M.R., Evans, R.D., Evans, S.N., Field, S.N., Friedman, K.J., Gilmour, J.P., Holmes, T.H., Middlebrook, et al., 2012. Unprecedented mass bleaching and loss of coral across $12^{\circ}$ of latitude in Western Australia in 2010-11. PLoS ONE e51807, 7.

Morin, S., Bonet, B., Corcoll, N., Guasch, H., Bottin, M., Coste, M., 2015. Cumulative stressors trigger increased vulnerability of diatom communities to additional disturbances. Microb. Ecol. 70, 585-595.

Ogilvie, B.G., Mitchell, S.F., 1998. Does sediment resuspension have persistent effects on phytoplankton? Experimental studies in three shallow lakes. Freshw. Biol. 40, 51-63.

Ohgai, M., Iwano, H., Hashijima, M., 1986. The effect of the environmental factors on the growth of diatom Cylindrotheca closterium (Ehrenberg) Reimann et Lewin [Injurious seaweed for laver culture]. Bulletin of the Japanese Society of Scientific Fisheries (Japan).

Olenina, I., et al., 2006. Biovolumes and Size-classes of Phytoplankton in the Baltic Sea.

Poloczanska, E.S., Brown, C.J., Sydeman, W.J., Kiessling, W., Schoeman, D.S., Moore, P.J., Brander, K., Bruno, J.F., Buckley, L.B., Burrows, M.T., et al., 2013. Global imprint of climate change on marine life. Nat. Clim. Chang. 3, 919-925.

Purves, W.K., Sadava, D., Heller, C., Orians, G.H., 2001. Life, the Science of Biology.

Rose, T., Smale, D., Botting, G., 2012. The 2011 marine heat wave in Cockburn Sound, southwest Australia. Ocean Sci. 8, 545-550.

Sasaki, T., Lauenroth, W.K., 2011. Dominant species, rather than diversity, regulates temporal stability of plant communities. Oecologia 166, 761-768.

Schlie, C., Woelfel, J., Rüdiger, F., Schumann, R., Karsten, U., 2011. Ecophysiological performance of benthic diatoms from arctic waters. In: The Diatom World. Springer, pp. 421-436.

Segner, H., Schmitt-Jansen, M., Sabater, S., 2014. Assessing the Impact of Multiple 
Stressors on Aquatic Biota: The Receptor's Side Matters. ACS Publications.

Seifert, L.I., Weithoff, G., Vos, M., 2015. Extreme heat changes post-heat wave community reassembly. Ecol. Evol. 5, 2140-2148.

Sloth, N.P., Riemann, B., Nielsen, L.P., Blackburn, T., 1996. Resilience of pelagic and benthic microbial communities to sediment resuspension in a coastal ecosystem, Knebel Vig, Denmark. Estuar. Coast. Shelf Sci. 42, 405-415.

Sommer, U., 1989. The role of competition for resources in phytoplankton succession. In: Sommer, U. (Ed.), Plankton Ecology. Springer Verlag, Berlin, pp. 55-106.

Sorte, C.J., Fuller, A., Bracken, M.E., 2010. Impacts of a simulated heat wave on composition of a marine community. Oikos 119, 1909-1918.

Steege, V., Köthe, H., 2015. Abschlussbericht des BMVI: Fachliche Schlussfolgerungen aus den Ergebnissen des Forschungsprogramms KLIWAS. BMVI, Bonn, pp. 111.

Steiner, C.F., Long, Z.T., Krumins, J.A., Morin, P.J., 2005. Temporal stability of aquatic food webs: partioning the effects of species diversity, species composition and enrichment. Ecol. Lett. 8, 819-828.

Steiner, C.F., Long, Z.T., Krumins, J.A., Morin, P.J., 2006. Population and community resilience in multitrophic communities. Ecology 87, 996-1007.

Stocker, T., 2014. Climate Change 2013: The Physical Science Basis: Working Group I Contribution to the Fifth Assessment Report of the Intergovernmental Panel on Climate Change. Cambridge University Press.

Stocker, T., Qin, D., Plattner, G.-K., Tignor, M., Allen, S., Boschung, J., Nauels, A., Xia, Y., Bex, V., Midgley, P., 2014. Climate Change 2013: The Physical Science Basis. Contribution of Working Group I to the Fifth Assessment Report of IPCC the
Intergovernmental Panel on Climate Change. Cambridge University Press.

Thiede, J., Aksnes, D., Bathmann, U., Betti, M., Boero, F., Cury, P., Dowell, M., Emmerson, R., Estrada, M., Fine, M., et al., 2016. Marine Sustainability in an Age of Changing Oceans and Seas: Report by the European Academies' Science Advisory Council (EASAC) and the Joint Research Centre (JRC) of the European Commission, EASAC Policy Report Luxembourg. pp. 58.

Thomas, M.K., Kremer, C.T., Klausmeier, C.A., Litchman, E., 2012. A global pattern of thermal adaptation in marine phytoplankton. Science 338, 1085.

Valiela, I., 2013. Marine Ecological Processes. Springer Science \& Business Media.

Vinebrooke, R.D., Cottingham, K.L., Norberg, J., Scheffer, M., Dodson, S.I., Maberly, S.C., Sommer, U., 2004. Impacts of multiple stressors on biodiversity and ecosystem functioning: the role of species co-tolerance. Oikos 104, 451-457.

Walker, B.H., Kinzig, A., Langridge, J., 1999. Plant attribute diversity, resilience, and ecosystem function: the nature and significance of dominant and minor species. Ecosystems 2, 95-113.

Walling, D.E., 2009. The Impact of Global Change on Erosion and Sediment Transport by Rivers: Current Progress and Future Challenges. Unesco.

Washington, H.G., 1984. Diversity, biotic and similarity indices. Water Res. 18, 653-694. Yachi, S., Loreau, M., 1999. Biodiversity and ecosystem productivity in a fluctuating environment: the insurance hypothesis. Proc. Natl. Acad. Sci. U. S. A. 96, 1463-1468.

Zehrer, R.F., Burns, C.W., Flöder, S., 2015. Sediment resuspension, salinity and temperature affect the plankton community of a shallow coastal lake. Mar. Freshw. Res. 66, 317-328. 